\title{
Animal performance, carcass traits and meat quality of F1 Angus- Nellore steers and heifers slaughtered in feedlot with a similar carcass finishing
}

\section{Desempenho animal, características de carcaça e qualidade da carne de novilhos e novilhas F1 Angus-Nelore abatidos em confinamento com similar grau de acabamento}

\author{
Wescley Faccini Augusto ${ }^{1 *}$; Ubirajara Oliveira Bilego ${ }^{2}$; Regis Luis Missio ${ }^{3}$; Tiago \\ Pereira Guimarães ${ }^{4}$; Fabrícia Rocha Chaves Miotto ${ }^{5}$; Pedro Leonardo de Paula \\ Rezende $^{6}$; José Neuman Miranda Neiva ${ }^{5}$; João Restle ${ }^{7}$
}

\begin{abstract}
The objective of this study was to evaluate the animal performance, carcass characteristics and meat quality of F1 Angus-Nellore steers and heifers, feedlot finished with high degree of subcutaneous fat deposition. The experimental design was completely randomized, with two treatments (steers and heifers) and 11 replicates (animals). Twenty-two bovines with initial age of 18 months of age, 11 steers and 11 heifers, with initial body weight of, respectively, $354.86 \pm 43,66$ and $353.82 \pm 39,80 \mathrm{~kg}$ were used. The animals were finished in confinement (114 days) with a diet containing $200 \mathrm{~g} \mathrm{~kg}^{-1}$ of corn silage and $800 \mathrm{~g} \mathrm{~kg}^{-1}$ of concentrate composed mainly of corn grain and soybean meal. The dry matter intake (9.42 vs. $\left.9.24 \mathrm{~kg} \mathrm{day}^{-1}\right)$, mean daily weight gain ( 1.44 vs. $\left.1.38 \mathrm{~kg} \mathrm{day}^{-1}\right)$, feed conversion (6.49 vs. 7.05 $\mathrm{kg}$ of dry matter kg-1 of weight gain), hot carcass weight (284.62 vs. $268.16 \mathrm{~kg}$ ) and the subcutaneous fat thickness (12.09 vs. $13.05 \mathrm{~mm})$ were similar between steers and heifers (respectively). The hot carcass yield was higher $(\mathrm{P}<0.05)$ for steers $(58.14$ vs. $55.53 \%)$. The steers presented a higher proportion of the forequarter (39.26 vs. $37.53 \%)$, while heifers had a higher proportion of pistol cut (49.87 vs. $48.85 \%)$. The meat of steers showed darker color $(\mathrm{P}<0.05)$. The shear force of the meat and marbling score did not differ between sexual conditions, with mean values of $5.43 \mathrm{kgf} \mathrm{cm}^{-2}$ and 10.14 points (median), respectively. Except for the proportion of primary cuts, carcass yield and meat color, F1 Angus-Nellore heifers present similar animal performance, carcass and meat characteristics in relation to steers, feedlot finished with high degree of subcutaneous fat deposition.
\end{abstract}

Key words: Average daily gain. Meat tenderness. Marbling. Carcass weight. Pistol cut.

\footnotetext{
1 Pós-Doutorado, Programa de Pós-Graduação em Ciência Animal Tropical, Universidade Federal do Tocantins, UFT, Araguaína, TO, Brasil. Bolsista da CAPES. E-mail: wescleyfaccini@hotmail.com

2 Pesquisador, Cooperativa Agroindustrial dos Produtores Rurais do Sudoeste Goiano, COMIGO, Rio Verde, GO, Brasil. E-mail: birabilego@hotmail.com

3 Prof., Departamento de Agronomia, Universidade Tecnológica Federal do Paraná, UTFPR, Pato Branco, PR, Brasil. E-mail: regisluismissio@gmail.com

4 Prof., Instituto Federal Goiano, IFGoiano, Campus Rio Verde, GO, Brasil. E-mail: tiagopereirarv@hotmail.com

5 Profs., Escola de Medicina Veterinária e Zootecnia, UFT, Araguaína, TO, Brasil. E-mail: fabriciarchaves@gmail.com; araguaia2007@gmail.com

6 Pós-Doutorado, Programa de Pós-Graduação em Ciência Animal, Universidade Federal de Goiás, UFG, Goiânia, GO, Brasil. E-mail: pedrozootec@hotmail.com

7 Prof., Programa de Pós-Graduação em Ciência Animal, UFG, Goiânia, GO, Brasil. Bolsista de Produtividade em Pesquisa do CNPq - Nível 1D. E-mail: jorestle@terra.com.br

* Author for correspondence
} 


\section{Resumo}

Objetivou-se avaliar o desempenho animal, as características de carcaça e a qualidade da carne de novilhos e novilhas F1 Angus-Nelore terminados em confinamento com similar grau de acabamento de carcaça. $\mathrm{O}$ delineamento experimental foi o inteiramente casualizado, com dois tratamentos (novilhos e novilhas) e 11 repetições (animais). Foram utilizados 22 bovinos com 18 meses de idade inicial, 11 novilhos e 11 novilhas, com peso corporal inicial de 354,86 $\pm 43,66$ e $353,82 \pm 39,80 \mathrm{~kg}$, respectivamente. Os animais foram terminados em confinamento (114 dias) com dieta contendo $200 \mathrm{~g} \mathrm{~kg}^{-1}$ de silagem de milho e $800 \mathrm{~g} \mathrm{~kg}^{-1}$ de concentrado composto principalmente por grão de milho moído e farelo de soja. $\mathrm{O}$ consumo de matéria seca (9,42 vs. $\left.9,24 \mathrm{~kg} \mathrm{dia}^{-1}\right)$, o ganho de peso médio diário (1,44 vs. 1,38 $\left.\mathrm{kg} \mathrm{dia}^{-1}\right)$, a conversão alimentar (6,49 vs. 7,05 kg de matéria seca kg-1 de ganho de peso), o peso de carcaça quente (284,62 vs. $268,16 \mathrm{~kg})$ e a espessura de gordura subcutânea (12,09 vs. 13,05 mm) foram similares entre novilhos e novilhas (respectivamente). $\mathrm{O}$ rendimento de carcaça quente foi maior $(\mathrm{P}<0,05)$ nos novilhos (58,14 vs. 55,53\%). Os novilhos apresentaram maior proporção de dianteiro (39,26 vs. $37,53 \%)$, enquanto as novilhas apresentaram maior proporção do traseiro especial (49,87 vs. 48,85\%). A carne dos novilhos apresentou coloração mais escura $(\mathrm{P}<0,05)$. A força de cisalhamento da carne e o marmoreio não diferiram entre as condições sexuais, com valores médios de, $5,43 \mathrm{kgf} \mathrm{cm}^{-2}$ e 10,14 pontos (mediano), respectivamente. Exceto em relação à proporção dos cortes primários, rendimento de carcaça e cor da carne, novilhas jovens F1 Angus-Nelore apresentam similar desempenho animal, características de carcaça e de carne em relação aos novilhos abatidos com similar grau de acabamento. Palavras-chave: Ganho médio diário. Maciez. Marmoreio. Peso de carcaça. Traseiro especial.

\section{Introduction}

Brazil is one of the largest producers and exporters of beef and needs to meet the global demand for beef in the coming decades. However, the low price paid for Brazilian beef in the international market is little discussed, even in the national literature. Although domestic and international prices reflect the low cost of production (primarily pasture production) and the large supply (the world's largest commercial herd), Brazilian meat has difficulty accessing markets that offer better prices (e.g., European Union, United States, and Japan) (ANUALPEC, 2017). This limitation is associated with animal diseases (especially foot-and-mouth disease) and the low quality of Brazilian beef, which is partly due to the high level of Zebu genes in the herds ( $80 \%$ of the national herd has Bos indicus genes) (FERRAZ; FELÍCIO, 2010). In addition, Silva et al. (2012) reported that seasonality in forage production and lack of nutritional planning are the primary obstacles for increasing the productivity and quality of Brazilian beef and result in older slaughter age and a small amount of carcass fat.
Among the technological alternatives to improve productivity and the insertion of Brazilian beef in the international market, what is important for the maintenance of prices in the domestic market, we can highlight the industrial crossbreeding and the feedlot finishingt. The British breeds, especially the Aberdeen Angus, are the most used in industrial crossing with Zebu because of the precocity of finishing and meat quality (THRIFT et al., 2010). However, the high productive performance of this cross requires differentiated nutritional conditions to avoid compromising investments in genetics and breeding strategies. In this context, confinement is an excellent option by allowing better control of the food supply (quantity and quality) and nutrient consumption compared to animals finished on pasture, among other advantages. In addition, high-grain and/or concentrated diets allow using this technology in regions with low capacity for producing high-quality forage (MISSIO et al., 2017).

In industrial crossbreeding, males and females are slaughtered, except in cases in which the use of the maternal heterosis of F1 females is desired. 
Although there are already quality payment programs in Brazil that allow similar remuneration between males and females, the marketing price of females is usually $10-15 \%$ lower than for males (PASCOAL et al., 2011). Studies with sexual classes are not new in the literature (VAZ et al., 2010a; PACHECO et al., 2011; ARANHA et al., 2018). However, the number of studies with sexual classes from the industrial crossbreeding in tropical conditions is incipient, notably between Aberdeen Angus and Nellore, the main breeds used in crossbreeding in Brazil.

The objective of this study was to evaluate the feedlot performance and carcass and meat characteristics of F1 Angus-Nellore steers and heifers with high degree of finishing.

\section{Materials and Methods}

The procedures used in this study were approved by the Animal Research Ethics Committee of the Federal University of Tocantins (Protocol N ${ }^{\circ}$ 213101.004264/2015-94).

The study was performed between July and September 2014 in the Centro Tecnológico da Cooperativa Agroindustrial dos Produtores Rurais do Sudoeste Goiano (CTC-COMIGO) located in the municipality of Rio Verde, Goiás, Brazil. Twentytwo crossbred F1 Angus-Nellore cattle (11 steers and 11 heifers) with a mean initial age of 18 months and initial mean body weight of $354 \pm 39 \mathrm{~kg}$ were used. The experimental design was a completely randomized design with two treatments (steers and heifers) and 11 replicates (animals).

The animals, offspring of primiparous Nellore cows inseminated with Aberdeen Angus semen, were weaned at the age of 9 months and reared on Panicum maximum cv. massai pasture with supplementation $(0.7 \%$ of live weight). Males were surgically castrated at the age of 13 months. At the age of 18 months, males and females were confined in individual stalls $\left(10 \mathrm{~m}^{2}\right)$, partially covered with concrete floor and containing individual water dispensers and troughs. Before the beginning of the study period (93 days), the animals were treated for helminth infections and underwent a 21-day period of adaptation to the facilities and the confinement diet. Animals were weighed at the beginning and end of the study period after 16-hour food fasting.

The animals were fed once daily (at 11:00 a.m.) with a diet containing $200 \mathrm{~g}$ of corn silage $\mathrm{kg}^{-1}$ of dry matter and $800 \mathrm{~g}$ of concentrate $\mathrm{kg}^{-1}$ of dry matter (Table 1). Food and leftovers were weighed daily, and feed was provided ad libitum. The leftovers were kept at $5 \%$ of the food supply. Samples of feed and leftovers were collected weekly, identified, and pre-dried in an oven with air ventilation forced to 55 ${ }^{\circ} \mathrm{C}$ for 72 hours.

Table 1. Centesimal and chemical composition of the diets (dry matter basis).

\begin{tabular}{|c|c|}
\hline Ingredients & $\mathrm{g} \mathrm{kg}^{-1}$ \\
\hline \multicolumn{2}{|c|}{ Centesimal chemical $\left(\mathrm{g} \mathrm{kg}^{1}\right)$} \\
\hline Corn silage & 200.00 \\
\hline Corn grain & 675.00 \\
\hline Soybean meal & 90.00 \\
\hline Urea & 5.00 \\
\hline Mineral nucleus** & 30.00 \\
\hline \multicolumn{2}{|c|}{ Chemical composition $\left(\mathrm{g} \mathrm{kg}^{1}\right)$} \\
\hline Dry matter ( $\mathrm{g} \mathrm{kg}^{-1}$ of natural matter) & 660.00 \\
\hline Ether extract & 38.00 \\
\hline
\end{tabular}


continuation

Crude protein

138.00

Neutral detergente fiber

210.00

Non-fibrous carbohydrates

592.00

Total carbohydrates

768.00

Levels of guarantee $\left(\mathrm{mg} \mathrm{kg}^{-1}\right)$ : Iron = 12,837.03; Copper = 3,793.51; Manganese = 10,004.52; Zinc = 24,103.95; Cobalt = 102.57; Iodine, 243.01; Selenium = 76.92; Monensin Sodium = 7,200. 0000; Vitamin E = 1,266.34; Antioxidant = 12,647.67; Magnesium $(\%)=7.10$; Sulfur $(\%)=46.55$; Vitamin A = 2024.57 UI/G; Vitamin D3 = 303.76 UI/G.

Dry matter (DM), ether extract (EE), and crude protein $(\mathrm{CP})$ were determined according to AOAC (1995). The neutral detergent fiber (NDF) content was determined according to Van Soest et al. (1991). Total carbohydrates and non-fibrous carbohydrates (NFC) were determined according to Sniffen et al. (1992) using the equations: $\mathrm{CT}=100-(\mathrm{CP}+\mathrm{EE}+$ $\mathrm{MM})$ and $\mathrm{NFC}=100-(\mathrm{CP}+\mathrm{EE}+\mathrm{MM}+\mathrm{NDF})$. The composition of the diets is shown in Table 1.

The animals were slaughtered in a commercial slaughterhouse with Federal Inspection System following the regular schedule of the slaughter line. The carcasses were labeled, divided in half, washed, and weighed. After that, the carcasses were cooled $\left(0^{\circ} \mathrm{C}\right)$ for 24 hours. The carcass conformation was evaluated on the left half-carcass considering the following classes (1-3, concave; 4-6, sub-rectilinear; 7-9, rectilinear; 10-12, subconvex; 13-15, convex; and 16-18, hyperconvex) was determined on the basis on the muscle profile. The physiological maturity (1-3 points, $>8.0$ years; $3-6$ points, 5.5-8.0 years; 7-9 points, 4.0-5.5 years; $10-12$ points, 2.5 4.0 years; $13-15$ points, $<2.5$ years) was determined on the basis of the degree of ossification of the spinal processes of the thoracic vertebrae according to the methodology of Müller (1987). The carcass yield was obtained by the ratio between the carcass weight and final body weight.

The left half of the carcass was separated into primary cuts, where the forequarter was separated from the pistol cut and short ribs between the $5^{\text {th }}$ and $6^{\text {th }}$ rib bone, including neck, shoulder, arm, and five ribs. Through the rib cut at $22 \mathrm{~cm}$ of the vertebral column, the pistol cut was separated from the short ribs, which included the ribs from the sixth bones on, plus the abdominal muscles.

The right half-carcass was cut between the $12^{\text {th }}$ and $13^{\text {th }}$ ribs to expose the Longissimus lumborun muscle, the tissue contour was traced in tracing paper, and the area was measured using the ImageJ software. In the same region, subcutaneous fat thickness (SFT) was determined by the arithmetic mean of three measurements. In the cranial portion of the Longissimus lumborun muscle, which was removed between the $10^{\text {th }}$ and $12^{\text {th }}$ ribs, the following parameters were evaluated subjectively: amount of intramuscular fat (1-3, traces; 4-6, slight; 7-9, small; 10-12, modest; 13-15, moderate; and 16-18, abundant), color (1, intense dark red; 2 , dark red; 3, slightly dark red; 4, red; and 5, bright red), and texture (1, very coarse; 2, coarse; 3 , slightly coarse; 4, fine; and 5, very fine) according to the methodology proposed by Müller (1987). The temperature and $\mathrm{pH}$ of the carcasses after 24 hours of slaughter were measured in the Longissimus lumborun muscle at the height of the $12^{\text {th }}$ rib using a Testo 205 portable digital $\mathrm{pH}$ meter.

A portion of the Longissimus lumborun muscle (between the $12^{\text {th }}$ and $13^{\text {th }}$ ribs) was collected in the right half-carcass to determine the shear force and chemical composition of the meat. The Longissimus lumborun muscle was properly packed and labeled and then frozen at $-20^{\circ} \mathrm{C}$. Two beef cuts (Nos. 1 and 2) from frozen samples were cut, including $2.54 \mathrm{~cm}$ of the cranial portion, perpendicular to the muscle fibers. Subsequently, the samples were weighed, 
sealed in plastic bags, and thawed in a domestic refrigerator at $4{ }^{\circ} \mathrm{C}$ for 24 hours. After thawing, beef cut No. 1 was again weighed to determine the thawing loss. The cuts were placed in an aluminum pan and baked in an electric oven until the internal temperature reached $70{ }^{\circ} \mathrm{C}$. The temperature was monitored using a heat-resistant probe coupled to a thermometer (Data Logger Testo 176T4). Beef cut No. 1 was weighed after cooling at room temperature. The difference between the initial and final weight of each beef cut corresponded to the cooking loss. The samples used to determine the cooking loss were packed in polyethylene and refrigerated for 24 hours at $4{ }^{\circ} \mathrm{C}$ to determine the shear force. For this purpose, six $1 \mathrm{~cm}^{2}$-muscle bundles (cylinders) were cut from each beef perpendicular to the muscle fibers and analyzed using a Warner-Bratzler Shear ${ }^{\circledR}$ texturometer.

Beef cut No. 2 was thawed at $4{ }^{\circ} \mathrm{C}$ for 24 hours. After that, the samples were ground using a domestic grinder and pre-dried in a greenhouse with forced air circulation at $55{ }^{\circ} \mathrm{C}$ for 72 hours. The moisture content was determined after heating the samples in a forced air circulation oven at 105 ${ }^{\circ} \mathrm{C}$ for 72 hours. The ash content was determined by muffle incineration at $600{ }^{\circ} \mathrm{C}$ for 4 hours. $\mathrm{CP}$ and EE were determined according to the methodology described by AOAC (1995).

The data were subjected to analysis of normality and homogeneity of variance. The data with normal distribution were subjected to analysis of variance, and an F-test was used to compare the means. The
Kruskal-Wallis test was performed to compare the means for non-parametric variables. Statistical analyses were performed using the SISVAR software version 5.3 (FERREIRA, 2011) at a level of significance of $5 \%$. The general equation used was:

$$
Y_{i j}=\mu+T_{i}+€_{i j}
$$

where $Y_{i j}$ is the dependent variable, $\mu$ is the overall mean, $T_{i}$ is the effect of treatments, and $€_{i j}$ is the experimental error.

\section{Results and Discussion}

The dry matter intake (DMI), expressed in $\mathrm{kg}$ day $^{-1}$ and $\mathrm{g} \mathrm{kg}^{-1}$ of body weight, was not significantly different $(\mathrm{P}>0.05)$ between steers and heifers (Table 2). These results were similar to those obtained by Fernandes et al. (2007) and Paulino et al. (2008), whereby the DMI of steers was similar to that of young bulls and heifers whereas the DMI of heifers was lower than that of young bulls. These authors suggest that DMI variations between young bulls and heifers are due to the difference in sexual maturity, and this difference did not occur between steers and heifers, as observed in the present study (Table 3). According to the NRC (1996), the degree of sexual maturity has a strong effect on food consumption, and the increase of $1 \%$ in body fat determines a decrease of $2.7 \%$ in DMI. According to the NRC (1996), heifers are physiologically older than males at a given age and weight range, and consequently may ingest less feed.

Table 2. Performance of F1 Angus-Nellore heifers finished in feedlot.

\begin{tabular}{|c|c|c|c|c|}
\hline \multirow{2}{*}{ Variables } & \multicolumn{2}{|c|}{ Sexual classes } & \multirow{2}{*}{ CV $(\%)$} & \multirow{2}{*}{$\mathrm{P}$ - valor } \\
\hline & Steers & Heifers & & \\
\hline Initial body weight, $\mathrm{kg}$ & 354.86 & 353.82 & 11.40 & 0.952 \\
\hline Initial body condition, points & 2.91 & 3.05 & 8.43 & 0.935 \\
\hline Dry matter intake, $\mathrm{kg}$ day $^{-1}$ & 9.42 & 9.24 & 9.66 & 0.656 \\
\hline Dry matter intake, $\mathrm{g} \mathrm{kg}^{-1}$ of body weight & 22.60 & 22.00 & 8.68 & 0.495 \\
\hline Average daily gain, $\mathrm{kg}$ day $^{-1}$ & 1.44 & 1.38 & 17.51 & 0.553 \\
\hline
\end{tabular}


continuation

Final body weight, $\mathrm{kg}$

Final body condition, points

$\mathrm{FC}, \mathrm{kg}$ of dry matter $\mathrm{kg}^{-1}$ de weight gain

$\mathrm{FC}=$ feed conversion $\mathrm{CV}=$ Coefficient of variation; $\mathrm{P}=$ Probability

Table 3. Carcass characteristics of confined Angus-Nellore F1 steers and heifers.

\begin{tabular}{|c|c|c|c|c|}
\hline \multirow{2}{*}{ Variables } & \multicolumn{2}{|c|}{ Sexual classes } & \multirow{2}{*}{ CV $(\%)$} & \multirow{2}{*}{$\mathrm{P}$ - valor } \\
\hline & Steers & Heifers & & \\
\hline Hot carcass weight, $\mathrm{kg}$ & 284.62 & 268.16 & 11.40 & 0.235 \\
\hline Cold carcass weight, $\mathrm{kg}$ & 281.02 & 265.90 & 11.10 & 0.256 \\
\hline Hot carcass yield, $\%$ do BW & 58.14 & 55.53 & 3.63 & 0.007 \\
\hline Cold carcass weight, $\%$ do BW & 57.50 & 55.20 & 7.09 & 0.008 \\
\hline Subcutaneous fat thickness, mm & 12.09 & 13.05 & 16.84 & 0.302 \\
\hline Physiological maturity, points & 13.64 & 13.18 & 23.32 & 0.074 \\
\hline Carcass conformation, points & 11.73 & 12.36 & 19.08 & 0.314 \\
\hline Longissimus lumborun area(LDA), $\mathrm{cm}^{2}$ & 70.26 & 70.84 & 8.47 & 0.822 \\
\hline LDA, $\%$ of cold carcass weight & 25.17 & 26.81 & 9.56 & 0.138 \\
\hline Forequarter, $\%$ of cold carcass weight & 39.26 & 37.53 & 2.53 & 0.001 \\
\hline Pistol cut, $\%$ of cold carcass weight & 48.85 & 49.87 & 1.24 & 0.001 \\
\hline Short ribs, $\%$ of cold carcass weight & 11.89 & 12.60 & 10.49 & 0.184 \\
\hline
\end{tabular}

$\mathrm{BW}=$ body weight $\mathrm{CV}=$ Coefficient of variation; $\mathrm{P}=$ Probability.

The average daily gain (ADG) and final body weight (FBW) were not significantly different $(\mathrm{P}>$ 0.05 ) between steers and heifers, which is attributed to a similar DMI (Table 2). These results are consistent with those reported by Fernandes et al. (2007) and Paulino et al. (2008), wherein productive performance was not significantly different between finishing steers and heifers. However, similar productive performance between steers and heifers is not a consensus in the literature. Marcondes et al. (2008) found that the ADG of steers of a genetic group similar to that of this study or Nellore steers was $22.3 \%$ higher than that of heifers, and this result was associated with a higher percentage of fat in heifers relative to steers. In this context, the NRC (2000) indicates that the ADG of steers is 20\% higher than that of heifers because of differences in sexual maturity between these animal groups at the same age and/or body weight.
Body condition was not significantly different ( $\mathrm{P}$ $>0.05$ ) between steers and heifers, which is attributed to a large extent to the similar ADG (Table 2). The NRC (1996) notes that higher rates of weight gain lead to higher rates of body fat deposition. In addition to the weight gain rates, the experimental diet, which contained a high percentage of concentrate $(80 \%$ of the DM), together with the effect of the Aberdeen Angus genotype, characterized by early slaughter age, resulted in high rates of fat deposition and similar filling of the interstitial space with adipose tissue between muscle tissue and endodermis in the study period. It should be noted that the sequence of fat deposition in the carcass is intermuscular fat, subcutaneous fat, and intramuscular fat (Di MARCO, 1998). The filling of the interstitial spaces in the muscle tissue and between the muscle tissue and endodermis represents a physical limitation for the deposition of intermuscular and subcutaneous 
fat, respectively, resulting in an increase in the rate of marbling deposition, which is limited by the number adipocytes and the space between these cells (BERG; BUTTERFIELD, 1976).

Feed conversion (FC) was not significantly different $(\mathrm{P}>0.05)$ between steers and heifers, which is explained by the similar DMI and ADG of these animals (Table 2). Among young animals, differences in FC were reported between young bulls and heifers; however, there were no significant differences in FC between steers and heifers (FERNANDES et al., 2007; MARCONDES et al., 2008; PAULINO et al., 2008). FC indicates the cost of production and, consequently, profit margin. These results demonstrate that heifers can be used for meat production in intensive production systems. However, it is of note that the price of heifers is $10-15 \%$ lower than that of steers (PASCOAL et al., 2011). Therefore, the use of heifers is in line with market requirements, especially in markets demanding high-quality meat. The use of Aberdeen Angus in commercial crosses is relevant because of the positive effect of these crosses on the quality of carcass and meat (THRIFT et al., 2010), which is reflected on the commercialization price of heifers, and prices can be similar to that of steers in qualitybased payment programs (FLORES, 2016).

The hot carcass (HCW) and cold carcass weight $(\mathrm{CCW})$ were not significantly different $(\mathrm{P}>0.05)$ between steers and heifers, which can be attributed to the similar slaughter weight and carcass finishing (Table 3). These results were similar to those reported by Fernandes et al. (2007), wherein there were no significant differences in carcass weight between Canchim steers and heifers finished in confinement. In contrast, Marcondes et al. (2008) found that the carcass weight of Nellore heifers was smaller than that of castrated and uncastrated males, and this result was attributed to differences in slaughter weight due to different growth rates between the sexes (lower in heifers). These results and those of other studies (FERNANDES et al., 2007; PAULINO et al., 2008) demonstrate that there are no significant differences in carcass weight or empty body weight between finishing heifers and steers with similar slaughter weight. These aspects should be considered for adequate management of heifers finished in confinement. In addition, the genetic group and energy level of the diets seem to be important because in Nellore animals fed with less energetic diets $(32 \%$ and $38 \%$ of concentrate in the diet), the productive performance and carcass weight of heifers may be lower than that of steers (MARCONDES et al., 2008).

The hot carcass (HCY) and cold carcass yield $(\mathrm{CCY})$ were significantly higher $(\mathrm{P}<0.05)$ in steers than in heifers (Table 3). Considering the similar FBW and subcutaneous fat thickness (SFT) of the animals, the results suggest that heifers had higher participation in non-carcass components, especially visceral fat, whose deposition occurred later than other body fats (BERG, BUTTERFIELD, 1976). Vaz et al. (2010b) evaluated the factors associated with carcass yield in young steers and heifers and demonstrated that the lower carcass yield of heifers was due to the higher percentage of hide, inguinal fat, digestive tract, and udder relative to the fat layer of steers. Nonetheless, these authors indicated that heifers had a lower slaughter weight than steers $(310.3$ vs. $365.8 \mathrm{~kg})$, which may have contributed to the obtained results.

These results are in line with those obtained by Marcondes et al. (2008), whereby HCY and CCY were similar between young bulls, steers, and heifers. The differences between our results and those of Marcondes et al. (2008) may be related to the carcass finishing because the SFT in the present study was almost twice that of the animals from the aforementioned study $(6.24 \mathrm{~mm})$. Similarly, Fernandes et al. (2007) found that HCY was similar between steers and heifers because of the similar slaughter weight and carcass weight between the sexes. It is worth noting that the SFT determined by Fernandes et al. (2007) was not high $(5.06 \mathrm{~mm})$, indicating that the amount of visceral fat and trim fat was not very high. 
The SFT was not different $(\mathrm{P}>0.05)$ between steers and heifers, which can be attributed to the similar ADG and slaughter weight of the animals (Table 3). The SFT values exceeded the maximum value required by slaughterhouses $(6 \mathrm{~mm})$. Excess fat cover in carcasses may reduce the profit margin of the carcass because excess fat is removed during carcass processing. In this context, the increase in the amount of trim fat represents an increase in the production cost because the producer is not remunerated by this tissue, which demands a higher amount (2.25 times) of feed relative to muscle tissue, which is removed in small amounts during carcass processing. Considering the high SFT $(13.05 \mathrm{~mm})$ and CCW of heifers $(265.90 \mathrm{~kg})$, which were much higher than the minimum required by slaughterhouses ( $3 \mathrm{~mm}$ and $225 \mathrm{~kg}$, respectively), it can be inferred that F1 Angus-Nellore heifers fed diets with a high proportion of concentrate can be slaughtered with a lower body weight. In this respect, lower slaughter weight may result in less body fat deposition, especially trim fat, with consequent reduction of food consumption and feed cost.

These results are similar to those obtained by Fernandes et al. (2007), wherein there were no significant differences in the SFT between steers and heifers fed in confinement for 105 days with diets containing $60 \%$ of concentrate and slaughtered at 18 months. These authors attributed the similar SFT to the high energy value of the diets and the effect of the Canchim breed, which is characterized by the earlier deposition of subcutaneous fat compared to continental European breeds. Similarly, Marcondes et al. (2008) found no significant differences in the carcass finishing between steers and heifers fed for 105 days in confinement. These results were also corroborated by Paulino et al. (2008), in which the SFT was similar between steers and heifers fed diets containing $23.5 \%$ or $45.2 \%$ of concentrate because of the similar sexual maturity of the animals.

The physiological maturity of the carcasses was not different $(\mathrm{P}>0.05)$ between steers and heifers (Table 3). Males and females received the lowest scores (13-15 points, corresponding to $<2.5$ years) according to Müller's methodology (1987), which classifies carcasses by cartilage ossification. The similar physiological maturity of carcasses between steers and heifers may be associated with the early slaughter age (21 months), which may have prevented identifying significant differences in cartilage ossification. Vaz et al. (2010a) found no significant difference in the sexual maturity between Braford steers (13.7 points) and heifers (13.5 points) aged 14 months and finished on summer pasture (Pennisetum purpureum), despite the sex differences in slaughter weight. Similarly, Pacheco et al. (2011) reported that there were no significant differences in sexual maturity between Charolais steers (13.2 points) and heifers (13.4 points) aged 20 months fed diets containing 50\% concentrate and finished in confinement.

The carcass conformation and Longissimus lumborun area (LDA) were not different $(\mathrm{P}>0.05)$ between steers and heifers (Table 3 ). These results indicate a similar degree of muscular development between the sexes, which is explained by a similar degree of sexual maturity and carcass weight. These results are partially similar to those of Vaz et al. (2010a), who found no significant differences in carcass conformation between steers and heifers. However, these authors reported that the LDA of steers was higher than that of heifers. In contrast, Marcondes et al. (2008) found no significant differences in LDA between steers and heifers. The carcass conformation and LDA are indicators of the muscle yield of the carcasses. In this respect, Marcondes et al. (2008) found no significant differences in muscle yield between steers and heifers and Pacheco et al. (2011) found no significant differences in muscle yield and edible portion (muscle + fat) yield of carcasses between these two sexual classes. These results are relevant because they indicate that there is no significant difference in the yield of the edible portion of heifer carcasses relative to male carcasses. In practice, the lower yield of the edible portion of the carcass is used 
by slaughterhouses to justify the lower price paid to heifer carcass, which is a promising marketing strategy because the consumer cannot identify the sex of the animals from secondary commercial cuts, allowing charging a higher price for heifer meat.

The forequarter yield was higher $(\mathrm{P}<0.05)$ in the steers, while the pistol cut yield was higher in the heifers (Table 3). These results can be attributed to sexual dimorphism, in which the development of the thorax muscles is higher in males than females whereas the development of the round muscles is higher in females than males (BERG; BUTTERFIELD, 1976). In contrast, the short ribs yield was not different between steers and heifers, which can be attributed to the similar slaughter weight and carcass finishing. Previous studies have demonstrated that the short ribs yield is high because of the increase of fat deposition in the carcasses (COSTA et al., 2002; ARBOITTE et al., 2004). These results are consistent with those of Pacheco et al. (2011), wherein steers tended to have a higher forequarter yield whereas heifers tended to have a higher yield pistol cut. Similarly, Aranha et al. (2018) evaluated Guzerá animals finished on Urochloa brizantha cv. Marandu and found that steers presented a comparatively higher forequarter yield whereas heifers had higher yield of hindquarter. In contrast, Vaz et al. (2010a) evaluated Braford animals fattened on pasture of Lolium multiflorum + Avena strigosa and finished on pasture of Pennisetum purpureum and found that there was a tendency of higher forequarter yield in steer, higher short ribs yield in heifer, and a similar yield of hindquarter cuts between the sexes, and these results may be related to the higher slaughter weight of steers. It is worth noting that the higher pistol cut yield gives females commercial advantage because the most valued secondary commercial cuts are located in the hindquarter.

The initial and final temperature $(24 \mathrm{~h}$ after slaughter) of the carcass was similar $(\mathrm{P}>0.05)$ between steers and heifers (Table 4). These results may be because of the high and similar SFT values between the sexes. This variable has an essential protective function during carcass cooling, preventing the rapid decrease in internal temperature and the shortening of muscle fibers, and avoiding cold burning and excessive water loss (MÜLLER, 1987; SAVELL et al., 2005; MAGGIONI et al., 2012). It is of note that the final temperature $\left(4.32{ }^{\circ} \mathrm{C}\right)$ of the carcasses was lower than the recommended maximum $\left(5^{\circ} \mathrm{C}\right)$ adopted to ensure the microbiological quality of the meat (DAVE; GHALY, 2011).

Table 4. Meat characteristics of confined F1 Aberdeen Angus-Nellore steers and heifers.

\begin{tabular}{lcccc}
\hline \multirow{2}{*}{ Variables } & \multicolumn{2}{c}{ Sexual classes } & \multirow{2}{*}{ CV $(\%)$} & P - valor \\
\cline { 2 - 3 } & Steers & Heifers & & \\
\hline Initial temperature, ${ }^{\circ} \mathrm{C}$ & 38,33 & 38,77 & 2,19 & 0,230 \\
Final temperature, ${ }^{\circ} \mathrm{C}$ & 4,35 & 4,29 & 4,79 & 0,543 \\
$\mathrm{pH}$ final & 5,88 & 5,91 & 2,84 & 0,745 \\
Color, points & 3,17 & 3,50 & 15,43 & 0,031 \\
Marbling, points & 10,09 & 10,18 & 17,43 & 0,715 \\
Shear force, $\mathrm{kg} \mathrm{cm}^{-2}$ & 5,13 & 5,73 & 17,70 & 0,157 \\
Thawing loss, $\mathrm{g} \mathrm{kg}^{-1}$ & 111,70 & 105,10 & 24,04 & 0,555 \\
Cooking loss, $\mathrm{g} \mathrm{kg}^{-1}$ & 288,50 & 288,50 & 7,55 & 0,996 \\
Total loss, $\mathrm{g} \mathrm{kg}{ }^{-1}$ & 400,30 & 393,60 & 8,42 & 0,643 \\
Texture, points & 4,12 & 4,25 & 19,05 & 0,355 \\
\hline
\end{tabular}

$\mathrm{CV}=$ Coefficient of variation; $\mathrm{P}=$ Probability. 
There was no significant difference in the final $\mathrm{pH}$ (24 hours after slaughter) between steers and heifers (Table 4), indicating that the pre-slaughter muscle glycogen content was not limiting because the $\mathrm{pH}$ values of the carcass were below the threshold value (6.0). Values higher than 6.0 may result in the development of dark, firm, and nonexudative meat (ALVES et al., 2005). The carcass $\mathrm{pH}$ is a result of the release of protons $\left(\mathrm{H}^{+}\right)$during glycolysis, when glycogen is used as fuel to produce anaerobic energy during muscle metabolism after death (HOCQUETTE et al., 1998; ROBERGS et al., 2004). High $\mathrm{pH}$ values were reported in the carcass of uncastrated males, which was associated with the depletion of muscle glycogen due to animal stress when kept in herds before slaughter (KUSS et al., 2009). Page et al. (2001) evaluated 1,000 bovine carcasses and found that $\mathrm{pH}$ in the carcass of bulls was higher than that of steers and heifers; nonetheless, there were no significant differences in this characteristic between steers and heifers. The decrease in $\mathrm{pH}$ is relevant because it favors enzymatic proteolysis and meat tenderness (HUFFLONERGAN; LONERGAN, 2005). In contrast, higher $\mathrm{pH}$ results in a lower oxidation-reduction potential, reducing the formation of myoglobin, which is essential for producing an attractive color (bright red) (ABRIL et al., 2001).

Steers presented meat with a darker color relative to heifers $(\mathrm{P}<0.05)$, although the hue was the same (slightly dark red) according to the methodology used (MÜLLER, 1987) (Table 4). These results were not expected because there were no significant differences in carcass $\mathrm{pH}$, and meat color is primarily associated with animal age because the concentration of myoglobin increases with advancing age (OURY et al., 2009). In addition, these results are not consistent with previous findings (VAZ et al., 2010a; PACHECO et al., 2011; ARANHA et al., 2018), which found no significant differences in meat color between steers and heifers. Notwithstanding, Page et al. (2001) found that heifer meat was darker than steer meat, suggesting that the effect of animal gender on meat color may be due to the effect of fat thickness on muscle. In the present study, it was not possible to identify the factors that improved the color of heifer meat. However, it should be emphasized that color is the main determinant of meat purchase because darker colors are associated with meat deterioration, and the improvement in this characteristic also benefits final sellers, achieving higher sales (MISSIO et al., 2010).

Meat marbling was similar $(\mathrm{P}>0.05)$ between steers and heifers (Table 4$)$. These results may be due to the high rates of weight gain and a large amount of carcass fat because, as with other body fats, intramuscular fat deposition may have a physical limitation associated with the number of adipocytes and the spaces between these cells (BERG; BUTTERFIELD, 1976). Aranha et al. (2018) observed that the amount of meat marbling was similar between steers and heifers, which was attributed to the energy level of the diets. In contrast, Pacheco et al. (2011) found that meat marbling was similar between cows and steers and higher than that of heifers, and this result was attributed to the higher carcass weight of the former two categories relative to heifers. Nonetheless, these authors found no significant differences between these animal groups when marbling content was expressed as a function of CCW. In contrast, Vaz et al. (2010a) found that marbling content was higher in Braford heifers than in steers of the same genetic group slaughtered at 14 months, demonstrating that earlier fat deposition in heifers is evidenced at younger ages.

The shear force of the muscle fibers was not significantly different between steers and heifers (Table 4), and the obtained values (5.13-5.73 $\mathrm{kgf}$ $\mathrm{cm}^{-2}$ ) correspond to tender meat because values smaller than $6.00 \mathrm{kgf} \mathrm{cm}^{-2}$ indicate meat tenderness (SHACKELFORD et al., 1997). The similar tenderness between steer and heifer meat, measured by the shear strength of muscle fibers, may be associated with the similar slaughter age, which 
is the main determining factor for the increase of connective tissue and insoluble collagen, which increase with advancing age and reduce tenderness (CRANWELL et al., 1996). Pacheco et al. (2011) found no significant differences in meat tenderness between steers, heifers, and cull cows. These authors attributed the similar values between cull cows and the other categories to the synthesis of unstable collagen during weight gain, as occurs during compensatory gain, resulting in a low percentage of stable collagen relative to total collagen, which contributes to the high tenderness of the meat. Similarly, Vaz et al. (2010a) and Aranha et al. (2018) found no significant differences in meat tenderness between steers and heifers. Differences in meat tenderness between males and females of the same age can be expected when uncastrated males are used because young bulls have a higher collagen content in the meat compared to heifers, and the same occurs in older animals compared to younger animals (BUREŠ́ BARTOŇ, 2012).

Thawing loss, cooking loss, and total water loss were not significantly different $(\mathrm{P}>0.05)$ between steers and heifers (Table 4). These results can be attributed to the similar carcass fat and marbling content, which represent physical barriers to water loss, and a similar meat $\mathrm{pH}$. Similar results were obtained by Vaz et al. (2010a) and Pacheco et al. (2011), wherein there were no significant differences in water loss during carcass processing of steers and heifers, which was mainly attributed to the similar fat content in the carcass (especially SFT and marbling content) and similar stress levels of the animals before slaughter. Pre-slaughter stress can decrease meat $\mathrm{pH}$ and the water-holding capacity. The presence of water in muscle tissue is a result of the water-holding capacity of muscle proteins, particularly myofibrils, which bind large amounts of water to polar groups via hydrogen bonds, and water concentration in the muscle is decreased as the polar groups are blocked. Therefore, the faster the post-mortem glycolysis, lower is the $\mathrm{pH}$ and the water-holding capacity (HUFF-LONERGAN; LONERGAN, 2005).

Meat texture was not significantly different ( $\mathrm{P}$ $>0.05$ ) between steers and heifers (Table 4). Meat texture refers to the granulometry of muscle fibers, and its variation is highly dependent on animal age so that meat texture in younger animals is finer and softer than in older animals (MÜLLER, 1987). These results are in line with those verified in the literature (VAZ et al., 2010a; PACHECO et al. 2011), which found no significant differences in meat texture between steers and heifers.

The chemical composition of the meat was not significantly different $(\mathrm{P}>0.05)$ between steers and heifers, which may be strongly associated with the similar carcass finish and marbling content (Table 5). The similar carcass finish indicates the similar sexual maturity between animals of both sexes, and consequently a similar amount of carcass fat. The content of ether extract (EE), the most variable component of meat, is directly related to the amount of carcass fat (ABRAHÃO et al., 2005). In contrast, the moisture content depends on the intramuscular fat content because the adipose tissue retains less water than muscle fibers (PRADO et al., 2008). The protein and mineral content of the meat is the least variable parameters, and the obtained results are justified by the similar physiological maturity of the carcass and similar meat marbling because the protein and mineral content of muscle tissue is higher than that of adipose tissue. Bureš and Bartoň (2012) evaluated the chemical composition of the meat of young bulls and heifers and found that the higher percentage of muscle in the former resulted in a higher moisture and protein content, whereas heifer meat had a higher content of EE because of the relatively higher fat content in the carcass. 
Table 5. Meat chemical composition of F1 Aberdeen Angus-Nellore steers and heifers.

\begin{tabular}{|c|c|c|c|c|}
\hline \multirow{2}{*}{ Variables } & \multicolumn{2}{|c|}{ Sexual classes } & \multirow{2}{*}{$\mathrm{CV}(\%)$} & \multirow{2}{*}{$\mathrm{P}$ - valor } \\
\hline & Steers & Heifers & & \\
\hline Moisture, $\%$ & 73.00 & 72.54 & 2.44 & 0.327 \\
\hline Crude protein, $\%$ & 21.27 & 21.33 & 4.09 & 0.858 \\
\hline Ether extract, \% & 3.67 & 4.07 & 40.92 & 0.563 \\
\hline Mineral matter, \% & 1.09 & 1.05 & 6.84 & 0.196 \\
\hline
\end{tabular}

$\mathrm{CV}=$ Coefficient of variation; $\mathrm{P}=$ Probability.

These results are similar to those reported by Aranha et al. (2018), wherein there were no significant differences in the chemical composition of meat between steers and heifers. The similar chemical composition of the meat between the sexes reinforces the importance of females for beef cattle production, in which F1 heifers from the industrial crossing Aberdeen Angus $\times$ Nellore presented a similar productive potential, and the nutritional quality of the meat was similar to that of steers.

\section{Conclusion}

In conditions of improved carcass finish, heifers from the F1 generation of the Aberdeen Angus $\times$ Nellore commercial cross had a productive performance and physical-chemical quality of the meat similar to that of steers with equivalent body weight and subcutaneous fat thickness. However, heifers produced meat with better color than steers.

\section{Acknowledgments}

We are grateful to the Coordination for the Improvement of Higher Education Personnel (CAPES) for granting the scholarship to the first author.

\section{References}

ABRAHÃO, J. J.; PRADO, I. N.; PEROTTO, D.; MOLETTA, J. L. Características de carcaças e da carne de tourinhos submetidos a dietas com diferentes níveis de substituição do milho por resíduo úmido da extração da fécula de mandioca. Revista Brasileira de Zootecnia, Viçosa, MG, v. 34, n. 5, p. 1640-1650, 2005.

ABRIL, M.; CAMPO, M. M.; ÖNENÇ, A. Beef colour evolution as a function of ultimate $\mathrm{Ph}$. Meat Science, New York, v. 58, n. 1, p. 69-78, 2001. DOI: 10.1016/ S0309-1740(00)00133-9

ALVES, D. D.; GOES, R. H. T. B.; MANCIO, A. B. Maciez da carne bovina. Ciência Animal Brasileira, Viçosa, MG, v. 6, n. 3, p. 135-149, 2005.

\section{ANUÁRIO DA PECUÁRIA BRASILEIRA -} ANUALPEC. 24. ed. São Paulo: Instituto FNP, 2017. $288 \mathrm{p}$.

ARANHA, A. S.; ANDRIGHETTO, C.; LUPATINI, G. C.; MATEUS, G. P.; DUCATTI, C.; ROÇA, R. O.; MARTINS, M. B.; SANTOS, J. A. A.; LUZ, P. A. C.; UTSUNOMIYA, A. T. H.; ATHAYDE, N. B. Performance, carcass and meat characteristics of two cattle categories finished on pasture during the dry season with supplementation in different forage allowance. Arquivo Brasileiro de Medicina Veterinária e Zootecnia, Belo Horizonte, v. 70, n. 2, p. 517-524, 2018. DOI: 10.1590/1678-4162-9576

ARBOITTE, M. Z.; RESTLE, J.; ALVES FILHO, D. C.; PASCOAL, L. L.; PACHECO, P. S.; SOCCAL, D. C. Características da carcaça de novilhos $5 / 8$ Nelore-3/8 Charolês abatidos em diferentes estádios de desenvolvimento. Revista Brasileira de Zootecnia, Viçosa, MG, v. 33, n. 4, p. 969-977, 2004.

ASSOCIATION OF OFFICIAL ANALYTICAL CHEMISTS - AOAC. Official methods of analysis. $16^{\text {th }}$ ed. Arlington: AOAC International, 1995. 1025 p.

BERG, R. T.; BUTTERFIELD, R. M. New concepts of cattle growth. Sydney: Sydney University, 1976. 240 p.

BUREŠ, D.; BARTOŇ, L. Growth performance, carcass traits and meat quality of bulls and heifers slaughtered at different ages. Czech Journal Animal Science, Ostrava, v. 57, n. 1, p. 34-43, 2012. 
COSTA, E. C.; RESTLE, J.; VAZ, F. N.; ALVES FILHO, D. C.; BERNARDES, R. A. L.; KUSS, F. Características da carcaça de novilhos Red Angus superprecoces abatidos com diferentes pesos. Revista Brasileira de Zootecnia, Viçosa, MG, v. 31, n. 1, p. 119-128, 2002.

CRANWELL, C. D.; UNRUH, J. A.; BRETHOUR, J. R.; SIMMS, D. D. Influence of steroid implants and concentrate feeding on carcass and longissimus muscle sensory and collagen characteristics of cull beef cows. Journal Animal Science, Champaign, v. 74, n. 8, p. 17771783, 1996. DOI: $10.2527 / 1996.7481777 x$

DAVE, D.; GHALY, A. E. Meat spoilage mechanisms and preservation techniques: a critical review. American Journal of Agricultural and Biological Sciences, New York, v. 6, n. 4, p. 486-510, 2011.

DI MARCO, O. N. Crescimiento de vacunos para carne. Mar Del Plata: Balcare, 1998. 246 p.

FERNANDES, A. R. M.; SAMPAIO, A. A. M.; HENRIQUE, W.; PERECIN, D.; OLIVEIRA, E. A.; TÚlLIO, R. R. Avaliação econômica e desempenho de machos e novilhas Canchim em confinamento alimentados com dietas à base de silagem de milho e concentrado ou cana-de-açúcar e concentrado contendo grãos de girassol. Revista Brasileira de Zootecnia, Viçosa, MG, v. 36, n. 4, p. 855-864, 2007.

FERRAZ, F. B. S.; FELÍCIO, P. E. Production systems an example from Brazil. Meat Science, New York, v. 84, n. 2, p. 238-243, 2010. DOI: 10.1016/j.meatsci.2009.06.006

FERREIRA, D. F. Sisvar: a computer statistical analysis system. Ciência e Agrotecnologia, Lavras, v. 35 , n. 6, p. 1039-1042, 2011. DOI: 10.1590/S141370542011000600001

FLORES, D. E. Programa carne angus certificada: procedimentos da certificação. 2016. Monografia (Especialização em Produção, Tecnologia e Higiene de Alimentos de Origem Animal) - Universidade Federal do Rio Grande do Sul, Porto Alegre. Disponível em: https://www.lume.ufrgs.br/bitstream/handle/ 10183/169305/001049883.pdf? sequence=1. Acesso em: 10 nov. 2018.

HOCQUETTE, J.F.; ORTIGUES-MARTY, I.; PETHICK, D.; HERPIN, P.; FERNANDEZ, X. Nutritional and hormonal regulation of energy metabolism in skeletal muscles of meat-producing animals. Livestock Production Science, New York, v. 56, n. 2, p. 115-143, 1998. DOI: 10.1016/S0301-6226(98)00187-0

HUFF-LONERGAN, E.; LONERGAN, S. M. Mechanisms of water-holding capacity of meat: the role of postmortem biochemical and structural changes. Meat Science, New York, v. 71, n. 1, p. 194-204, 2005.
KUSS, F.; LÓPES, J.; BARCELLOS, J. O. J.; RESTLE, J.; MOLETTA, J. L.; PEROTTO, D. Características da carcaça de novilhos não-castrados ou castrados terminados em confinamento e abatidos aos 16 ou 26 meses de idade. Revista Brasileira de Zootecnia, Viçosa, MG, v. 38, n. 3, p. 515-522, 2009.

MAGGIONI, D.; PRADO, I. N.; ZAWADZKI, F.; VALERO, M. V.; MARQUES, J. A.; BRIDI, A. M.; MOLETTA, J. L.; ABRAHÃO, J. J. Grupos genéticos e graus de acabamento sobre qualidade da carne de bovinos. Semina: Ciência Agrárias, Londrina, v. 33, n. 1, p. 391402, 2012. DOI: 10.5433/1679-0359.2012v33n1p391

MARCONDES, M. I.; VALADARES FILHO, S. C.; PAULINO, P. V. R.; DETMANN, E.; PAULINO, M. F.; DINIZ, L. L.; SANTOS, T. R. Consumo e desempenho de animais alimentados individualmente ou em grupo e características de carcaça de animais Nelore de três classes sexuais. Revista Brasileira de Zootecnia, Viçosa, MG, v. 37, n. 12, p. 2243-2250, 2008.

MISSIO, R. L.; ALEXANDRINO, E.; SILVA, D. P.; PAULA NETO, J. J.; RESENDE, J. M.; MARINHO, A. A.; SILVA, D. V. Productive performance of confined young bulls fed proportions of Mulato II grass silage in the diet. Pesquisa Agropecuária Brasileira, Brasília, v. 52 , n. 8 , p. $670-678,2017$. DOI: $10.1590 / \mathrm{s} 0100-$ $204 \times 2017000800013$

MISSIO, R. L.; BRONDANI, I. L.; ALVES FILHO, D. C.; RESTLE, J.; ARBOITTE, M. Z.; SEGABINAZZI, L. R. Características da carcaça e da carne de tourinhos terminados em confinamento, recebendo diferentes níveis de concentrado na dieta. Revista Brasileira de Zootecnia, Viçosa, MG, v. 39, n. 7, p. 1610-1617, 2010.

MÜLLER, L. Normas para avaliação de carcaças e concurso de carcaça de novilhos. Santa Maria: Universidade Federal de Santa Maria, 1987. 32 p.

NATIONAL RESEARCH COUNCIL - NRC. Nutrient requirements of beef cattle. $7^{\text {th }}$. ed. rev. Washington: National Research Council, National Academy of Sciences, 1996. 242 p.

NATIONAL RESEARCH COUNCIL - NRC. Nutrient requirements of beef cattle: $7^{\text {th }}$ ed. rev. Update 2000 . Washington: The National Academies Press, 2000. 249 p.

OURY, M.; PIERRET, P.; COULMIER, D.; DUMONT, R. Eléménts de maitrise de la couleur des viandes chez les bovins de race Charolaise. Productions Animales, Paris, v. 22, n. 2, p. 131-140, 2009.

PACHECO, P. S.; RESTLE, J.; ALVES FILHO, D. C.; BRONDANI, I. L.; PASCOAL, L. L.; KUSS, F.; MENEZES, L. F. G.; NEIVA, J. N. M. Carcass physical composition and meat quality of Charolais cattle of 
different categories. Revista Brasileira de Zootecnia, Viçosa, MG, v. 40, n. 11, p. 2597-2605, 2011. DOI: 10.1590/S1516-35982011001100043

PAGE, J. K.; WULF, D. M.; SCHWOTZER, T. R. A survey of beef muscle color and pH. Journal of Animal Science, Champaign, v. 79, n. 3, p. 678-687, 2001. DOI: 10.2527/2001.793678x

PASCOAL, L. L.; VAZ, F. N.; VAZ, R. Z.; RESTLE, J.; PACHECO, P. S.; SANTOS, J. P. A. Relações comerciais entre produtor, indústria e varejo e as implicações na diferenciação e precificação de carne e produtos bovinos não carcaça. Revista Brasileira de Zootecnia, Viçosa, MG, v. 40, p. 82-92, 2011. Suplemento.

PAULINO, P. V. R.; VALADARES FILHO, S. C.; DETMANN, E.; VALADARES, R. F. D.; FONSECA, M. A.; VÉRAS, R. M. L.; OLIVEIRA, D. M. Desempenho produtivo de bovinos Nelore de diferentes classes sexuais alimentados com dietas contendo dois níveis de oferta de concentrado. Revista Brasileira de Zootecnia, Viçosa, MG, v. 37, n. 6, p. 1079-1087, 2008.

PRADO, I. N.; PRADO, R. M.; ROTTA P. P.; VISENTAINER, J. V.; MOLETTA, J. L.; PEROTTO, D. Carcass characteristics and chemical composition of the Longissimus muscle of crossbred bulls (Bos taurus indicus vs. Bos taurus taurus) finished in feedlot. Journal Animal Feed Science, Amsterdam, v. 17, p. 295-306, 2008.

ROBERGS, R. A.; GHIASVAND, F.; PARKER, D. Biochemistry of exercise-induced metabolic acidosis. American Journal of Physiology. Regulatory, Integrative and Comparative Physiology, Rockville, v. 287, n. 3, p. 502-516, 2004. DOI: 10.1152/ajpregu.00114.2004

SAVELL, J. W.; MUELLER, S. L.; BAIRD, B. E. The chilling of carcasses. Meat Science, New York, v. 70, n. 3, p. 449-459, 2005. DOI: 10.1016/j.meatsci.2004.06.027

SHACKELFORD, S. D.; WHEELER, T. L.; KOOHMARAIE, M. Evaluation of beef longissimus shear force at 1 or 2 days postmortem as a predictor of aged beef tenderness. Journal of Animal Science, Champaign, v. 75, n. 9, p. 2417-2422, 1997.
SILVA, N. R.; FERREIRA, A. C. H.; FATURI, C.; SILVA, G. F.; MISSIO, R. L.; NEIVA, J. N. M.; ARAÚJO, V. L. de; ALEXANDRINO, E. Desempenho em confinamento de bovinos de corte, castrados ou não, alimentados com teores crescentes de farelo do mesocarpo de babaçu. Ciência Rural, Santa Maria, v. 42, n. 10, p. 1882-1887, 2012.

SNIFFEN, C. J.; CONNOR, J. D. O.; VAN SOEST, P. J.; FOX, D. G.; RUSSELL, J. B. A net carbohydrate and protein system for evaluating cattle diets: II. Carbohydrate and protein availability. Journal of Animal Science, Champaign, v. 70, n. 11, p. 3562-3577, 1992. DOI: $10.2527 / 1992.70113562 x$

THRIFT, F. A.; SANDERS, J. O.; BROWN, M. A.; BROWN JÚNIOR, A. F.; HERRING, A. D.; RILEY, D. G.; DEROUEN, S. M.; HOLLOWAY, J. W.; WYATT, W. E.; VANN, R. C.; CHASE JÚNIOR, C. C.; FRANKE, D. E.; CUNDIFF, L. V.; AND BAKER, J. F. Review: preweaning, postweaning, and carcass trait comparisons for progeny sired by subtropically adapted beef sire breeds at various US locations. The Professional Animal Scientist, New York, v. 26, n. 5, p. 451-473, 2010.

VAN SOEST, P. J.; ROBERTTSON, J. B.; LEWIS, B. A. Methods for dietary fiber, neutral detergent fiber, and nonstarch polysaccharides in relation to animal nutrition. Journal of Dairy Science, Champaign, v. 74, n. 10 , p. $3583-3597,1991$. DOI: $10.3168 /$ jds.S00220302(91)78551-2

VAZ, F. N.; ARBOITTE, M. Z.; PASCOAL, L. L.; ALVES FILHO, D. C.; PACHECO, R. F. Características de carcaça e da carne de novilhos e novilhas superjovens, terminados com suplementação em pastagem cultivada. Ciência Animal Brasileira, Goiânia, v. 11, n. 1, p. 42-52, 2010a.

VAZ, F. N.; RESTLE, J.; ARBOITTE, M. Z.; PASCOAL, L. L.; FATURI, C.; JONER, G. Fatores relacionados ao rendimento de carcaça de novilhos ou novilhas superjovens, terminados em pastagem cultivada. Ciência Animal Brasileira, Goiânia, v. 11, n. 1, p. 53-61, 2010 b. 